\title{
IMPROVING THE QUALITY OF HIGHER EDUCATION: LESSONS FROM RESEARCH ON STUDENT LEARNING AND EDUCATIONAL LEADERSHIP $^{1}$
}

\author{
PAUL RAMSDEN
}

\begin{abstract}
A few years ago David Minton published a book about teaching skills in adult education. ${ }^{2}$
\end{abstract}
To introduce an idea about the importance of the teacher's experience as a key factor in the quality of learning and teaching, he described his own experience of eating a delicious dish of garlic mushrooms in a restaurant in the Beaujolais. Madame served, and her husband did the cooking. But Minton made a mistake. He asked Madame for the recipe. "Monsieur," came the withering reply "It is not what, it is who."

Minton realised then that he had asked the wrong question. The difference between one dish of garlic mushrooms and another does not depend on the recipe, but on the person who cooks it.

Much the same is true of the quality of university teaching and university courses. There are no certain prescriptions for good teaching. There are no foolproof techniques for guaranteeing quality. There are only teachers, and educational effectiveness depends on their professionalism, their experience, and their commitment. We must ask the right questions in the search for quality. We must emphasise the importance of the "who" in order to achieve quality.

What does it take to improve the quality of learning and teaching in higher education? More importantly what will help us, as teachers, to achieve improvement? In this article I would like to illustrate how some of the ideas from student learning research might be used to improve the quality of university education. There are three areas I want to apply these lessons: helping the novice lecturer to become more expert; providing appropriate academic leadership; and using methods of evaluating teaching and courses which combine the need to assure quality with the principal purpose of enhancing it.

\section{THE IMPACT OF STUDENT LEARNING RESEARCH}

The main lessons from the last fifteen years of research into student learning will have an everyday ring to most readers. The ideas of a previously little-known group of academics from Britain and Sweden have become accepted into the discourse of quality in higher education. Powerful people and statutory bodies now use phrases from what used to be a comfortably private area of educational research as part of their lingua franca.

It seems now generally accepted that we need to look at students' learning in the natural environment in which it takes place. University students' experiences of teaching and assessment matter more than particular teaching methods in determining the effectiveness of their learning. Perhaps less embedded in academic culture, though it follows directly, is the idea that "teaching" means more than instructing and performing and extends more broadly to providing a context in which students engage productively with subject matter. There is a now a widespread view in academic development circles, derived directly from the student learning research, that we should concentrate on learning, on what the learner does and why the learner thinks he or she is doing it, rather than what the teacher does. ${ }^{3}$ And, if teaching is about helping to make learning possible, assessment becomes defined as being about understanding students and what they have learnt. Effective assessment helps students develop the skills of self-assessment.

I want to go beyond this, however. These examples can be translated into another set related to improving educational quality. University teaching takes place in a context, and understanding the 
academic's experience of academic work is a key to understanding how to improve it. Improving teaching is about helping to make teacher learning possible; evaluating teaching is about getting to know teachers and their teaching. Effective teaching is professional, self-evaluating teaching - and effective evaluation helps develop the skills of self-evaluation.

\section{IMPROVING TEACHING: HELPING NOVICES BECOME EXPERTS}

One reason for the impact of the research on student learning is that it reflects, in a special way, how accomplished teachers go about their work. The great body of research on teaching expertise makes it clear that the experts focus primarily about what their students are doing and thinking. Expert teachers look at teaching from the point of view of the learner, not the teacher. There is a strong association between this way of teaching and the quality and quantity of student learning.

Novices as well as experts use models or theories of teaching when they teach. Experts and novices express different conceptions of teaching, and different intentions underlie the strategies they use. ${ }^{4}$ For novice teachers, the immediate reality of class management, lecture notes, teaching materials, and numbers of students looms large. They want to do what I did when I gave my first lecture - to fit into the existing environment. How did my predecessor teach this class? How can I do the same? They see teaching primarily as telling or transmitting knowledge, and organising it so that it can be efficiently transferred from teacher to learner. Events in the classroom are interpreted from the teacher's point of view alone, and their implications for students' learning are rarely perceived. Novices typically believe that reflection on the effects of teaching on student learning is "only theory": they sharply distinguish educational theory from "reality".

The expert differs not only in terms of strategies and the effectiveness of his or her students' learning, but also in terms of conceptions and intentions. Naturally the expert teacher often does the things that a novice does. But something like class management, for example, does not usually occupy the foreground of his or her thinking. The expert thinks about teaching as interacting with students and monitoring their learning. This may involve some presentation of information, but that is only a step on the way; it is not what an expert thinks teaching is. He or she intends to make the educational environment, not simply respond to it, and sets the ground rules by making explicit what is expected from students as far as he or she is concerned, not by reference to other teachers. The expert is very alert to classroom events, and fully understands the value of reflection on practice as a way of adapting and improving.

Although you can tell teachers about effective strategies, this is not enough to improve their students' learning, since they will often not use them, or will misuse them, unless they also change their intentions and their conceptions. Failure to understand these relationships remains one of the serious errors of conventional staff development, just as it remains the fundamental misconception of conventional study skills courses. The mistake has been repeated in many texts on teaching methods in higher education. Too often, the lecturer's education in teaching methods has stopped at the strategies. Sometimes it encourages a split between conception and strategy by marginalising theory ("So much for the theory about how rats learn to run mazes. Now on to the real world of teaching large classes in a converted cigarette factory"). It is interesting that this dualist ontology — quite different from modern views of how professionals learn and practise - has been recently formalised in an unfavourable contrast between "practical strategies" and "theoretical ideas about teaching" in universities. ${ }^{5}$ The dualist conception embodies the novice's error. ${ }^{6}$

The results of ignoring the importance of teachers' conceptions in staff development are familiar to every staff developer. If you understand teaching as information transmission, and intend so to teach, how will you react to the suggestion that you should use buzz groups in lectures? Probably by saying that you do not have time for student activity; you will not be able to get through all the content. If you try a studentcentred strategy, you will probably not take it very seriously, and when it fails to work, you will probably abandon it rather than try to make it work; you may use it superficially in a way contrary to its purpose. Teaching strategies are important, and teachers must learn them; but they must learn them and change their understanding if the strategies are to lead to better student learning. ${ }^{7}$

These ideas about how university teachers learn to teach are expressed in the best of the programmes for new staff and accredited courses for lecturers in Australia and the UK. ${ }^{8}$ SEDA's scheme in particular 
represents exemplary practice in professional teacher education. We are seeing a change from a dualist model to a unified one, where ideas about how students learn and how assessment and teaching affect their learning are integrated with the experience of teaching. In these programmes, "classroom strategies" and "theory" are in constant dependence with each other, each taking its meaning from the other. The new pattern is similar to the general movement towards more problem-based and experience-driven professional education. ${ }^{9}$ It reflects today's understanding of how students and teachers learn.

A recent study of Australian new academic staff programmes provides support for the proposition that courses of this type lead to more effective teaching than the traditional ones..$^{10}$ It also confirms the conclusions of a long-term investigation of American courses for new faculty. ${ }^{11}$ The naive dualism of foundational theory versus teaching practice in university staff development is no longer tenable.

The best courses involve staff in a lengthy programme, related to their special needs alone, in which there are many opportunities for inter-colleague interaction. Even the most carefully designed course, however, may have little impact on teaching quality unless the much more powerful effect of the academic's normal environment - the department, school or faculty — is taken into account. There is no point in having great ideas about new ways to help students to learn if the departmental environment is hostile to their application. New academics soon abandon their innovatory strategies if their colleagues give them no encouragement to use them. They adapt to the context in which they find themselves. This is another commonplace of student learning research that we must apply to educational development.

\section{THE CONTEXT OF TEACHING: LEADERSHIP THAT ENABLES}

Recently I was discussing the problem of how to recognise and reward good university teaching with the Deputy Vice- Chancellor (Staffing) of an Australian university. The talk went through the usual topics: perceptions that good teaching went unrewarded in comparison with research; the issues of how to measure good teaching; the ways of altering promotion systems to take more account of teaching; the use of portfolios and the pitfalls of student ratings. Then he said, "Do you know the single most important thing that would lead to better teaching, and a feeling that good teaching is properly rewarded? Appoint the right Vice Chancellor".

He is right, of course. Promotions are a necessary but small part of recognising and rewarding the effort put into teaching. The problem is much more fundamental. It is a problem of environment and leadership. Its solution requires creating the conditions in which staff feel empowered to help their students. It involves helping them feel that their work is valued, and praising and supporting their efforts to assist their students, not ignoring or criticising them. It implies the time and the resources and the behaviour that helps teachers learn. It means helping them to learn from each other.

There is an analogy between what student learning research says about the effect of the context of learning on approaches to learning and the effects of the academic environment on approaches to teaching. Just as good teaching can encourage active engagement with academic content, so good leadership can encourage staff to give their best to their students. Good leadership helps create an environment for teacher learning and collaborative problem-solving.

Studies of school effectiveness demonstrate this point so faithfully ${ }^{12}$ that I am surprised at how little attention is still paid to academic leadership by educational developers in higher education. The nature of the principal's leadership is the crucial variable in determining the satisfaction and success of the staff. In a good school, where the children learn a great deal and the staff enjoy their work, the principal is typically someone who knows what he or she wants the school to achieve and helps teachers to work together towards shared goals. He or she is primarily interested in solving educational problems rather than administrative ones. These principals provide leadership that enables staff to operate as a team. They monitor the effects of their management strategies, striving continuously to improve them. They use consistent delegation policies. They model risk-taking in teaching. They emphasise educational values. They focus on the value of caring about students as a critical aspect of what the school does. They actively use knowledge and ideas from outside the school to improve what goes on within it. ${ }^{13}$

To push this analogy even further, the findings of studies of secondary school teachers' perceptions of what a good principal does reflect those of studies of students' perceptions of good teaching. ${ }^{14}$ The student 
learning research tells us about the importance of intellectual challenge, clear goals, creating an environment where they take responsibility for their own learning, encouraging cooperation between students, concern and respect for students as learners and people, understanding what students have learnt and what they still need to learn, giving excellent feedback on learning, continuously monitoring the effects of one's teaching in order to improve it, seeing teaching as a conversation or dialogue rather than a transmission process, and understanding teaching as a process of enabling learners, rather than a set of recipes.

Each of these factors in good teaching has a counterpart in effective academic leadership. If teaching is helping to make learning possible, educational leadership is helping to make effective teaching possible. Proficient academic leadership involves building a shared vision through establishing clear goals, improving communication, and creating challenge in an environment of collaborative decision making and teamwork where each individual feels a responsibility for achieving excellence in teaching and learning. It involves engaging in a conversation or dialogue with teachers. It implies encouraging staff to become involved in the process of evaluating and improving their teaching as a normal part of their work. Very importantly, it also implies putting ideas into practice through observable action - nothing is more disheartening than rhetoric about supporting good teaching that is not backed up by appropriate management behaviour that recognises the value of good teaching.

Viewed like this, leadership is indeed a process analogous to good teaching; and like good teaching, its highest aim is to achieve redundancy. Of the best teachers the students say "We learned it all without you". Of the best academic leaders the academics say "We did it all ourselves".

Investigations of research productivity generally support the argument that leadership and the academic context are important determinants of individual research output. Cooperatively- managed academic units with participative, goal-directed management lead to higher productivity. ${ }^{15}$ When researchers move from more supportive environments to less supportive ones, their productivity declines; and vice-versa. The context of research affects the researcher's activity and output.

Is this true about university teaching? How does the context of teaching affect the quality of teaching? Mike Prosser, Keith Trigwell, Elaine Martin and I are looking at the associations between the academic environment and lecturers' approaches to teaching in an Australian Research Council funded project. Trigwell and Prosser have previously identified different approaches to university teaching among science lecturers which are similar to the "knowledge transmission" versus "facilitating learning" conceptions of teaching which others have previously described. ${ }^{16}$ The different approaches are empirically connected to the use of different teaching strategies and, moreover, they appear to elicit different approaches to learning among students.

Our hypothesis now is that these approaches to teaching, like students' approaches to learning, are related to the perceived academic environment. We hope to be able to trace a path from departmental management to the quality of student learning (see Figure 1). Early indications ${ }^{17}$ are that perceptions of transformational leadership ("The head motivates you to do more in your teaching than you ever thought you could”), participatory management ("The head of this department listens to what you have to say") and teacher involvement ("People discuss their teaching problems with each other here") may well form a link between academic management and good teaching.

FIGURE 1

Leadership and the Quality of Student Learning

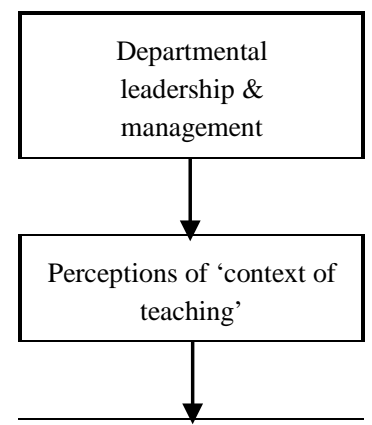




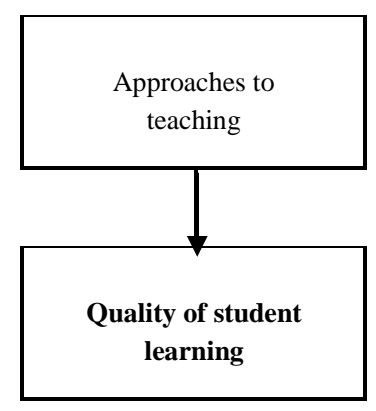

\section{ASSESSING EDUCATIONAL QUALITY: TAKING CONTROL OF EVALUATION}

According to the student learning research, assessment gives messages about the kind of learning required. If so, then evaluation gives messages about the kind of teaching required. The third area where student learning research impacts on educational quality is evaluation. Any credible scheme for evaluation has to take account of two apparently conflicting goals: the need to provide publicly-verifiable information for purposes of accountability and the need to develop a commitment to everyday self-evaluation for improvement purposes. If enhancing the quality of student learning is the primary goal, it is imperative to prevent the task of collecting and demonstrating from overwhelming the process of reflection and change. It is no use simply ignoring the need for rigorous reporting of good data, but it is no use either pretending that perceptions of the assessment process will not determine its effectiveness. Luckily, if we get the improvement part right, the accountability part is generally sure to follow. Good evidence of improvement is automatic evidence of accountability. ${ }^{18}$

If Minton is right about the importance of the "who" in teaching, then the methodology must build a sense of ownership in and responsibility for the process among teachers. Like a good student assessment regime, it should provide plenty of feedback and encourage openness and cooperative activity It should minimise anxiety and the sense of being continually inspected. It should be valid, beneficent, and fair. It should be the subject of a dialogue between assessors and assessed. It should not do anything that discourages people from trying to criticise their performance candidly and from trying to use the information they gather about their performance to enrich what they subsequently do. It should encourage responsible self-assessment. It should be integral to teaching and learning, rather than additional to teaching and learning. It must lead to trustworthy judgements about academic performance.

It is interesting that the process of quality assessment of Australian universities has, for all its other imperfections, used an evaluation model that is remarkably up to date and congruent with the student learning research findings about the effects of assessment on the quality of learning. Instead of using an expensive and clumsy inspection model, the Australian system has approached the problem by requiring reliable self-evaluation linked to institutional objectives, followed by external audit of the results of this process. The message that this system is trying to convey is that outcomes and evidence of improvement matter more than the existence of quality management processes in themselves; and that the responsibility for demonstrating excellence lies with the institution. The external assessment is an attempt to verify the university's claims. The results of the assessment are linked directly to funding incentives. There are immediate parallels with systems of student self-assessment.

Unfortunately the internal quality management processes of Australian universities have not always achieved the same level of rigour and fairness. The analogy is again appropriate: even the best assessment is sometimes interpreted by the students in a way different from the intentions of the teacher. In many cases far too much emphasis has been placed on quite trivial (but often costly) processes (such as the existence of compulsory student ratings of lecturers) which may have damaging side-effects on teacher morale and student goodwill, and too little on evidence of improvements in the quality of student learning outcomes. To use a geological time scale, millennia seem to have been spent on devising "objective" quantitative indicators, a day on what the indicators are supposed to indicate, an hour or two on whether the indications show that students are learning well, and seconds on whether their learning has improved. 
My conversations with quality managers in large corporations have convinced me of what I had never thought I would be convinced of - that universities have much to learn from the best industry practice on quality. Their approach to quality, unlike many of the universities', is closely aligned with the student learning research findings. Excellence in products and services requires a focus on cooperation (even between competitors in the same market, in benchmarking best practice, for example), commitment, rigour, ownership of processes and vision, adding value, and above all an environment where improvement is normal and support for improvement is freely given. In contrast the universities' approach to quality in learning and teaching often still reeks of unskilful assessment practice, especially a conception that high standards are the almost automatic consequence of high quality inputs (good students, good researchers, plenty of money), high pressure to perform, and high levels of secrecy and competition. No wonder that ICI Australia, Eastman Kodak and the rest are sceptical about the pretensions of higher education to claim a special place at the table of quality management. I have been involved in two schemes at Australian universities which have tried to grapple with the problem in a more adroit way. Both schemes draw in part on the excellent work of the Scottish Office Education Department in devising qualitative performance indicators for secondary schools, ${ }^{19}$ as well as on the lessons from student learning research, and the valuable work that has been done on student self-assessment in the past few years. It is absolutely necessary to provide course teams and departments with models on which they can base their self-evaluations, and suggested criteria which might be used. It is equally important to ensure that teaching staff develop ownership over the process, and that they find it useful.

The Griffith University scheme (Figure 2) is based on the principle that good universities, like good learners and good teachers, are constantly learning about how they can improve their performance. Quality improvement and the development of students are primary purposes. Separation is made between the process of evaluating individual teaching (column 3 ) and the process of evaluating courses and faculties (columns 1 and 2). ${ }^{20}$ Examples of excellent performance, phrased generally are provided initially to help course teams to evaluate different aspects of their work (see Figure 3). ${ }^{21}$ New examples related to particular disciplines are constantly being created from actual practice. Principles that guide the process are listed in Figure 4.

\section{FIGURE 2}

\section{Evaluating and Improving the Quality of Teaching and Learning at Griffith University}

Basic principles: The process of audit and improvement should be systematic, flexible, empowering, devolved, collaborative, and rigorous. A variety of different sources of evidence should be used. The process should consume the minimum amount of time and resources consistent with demonstrating accountability and genuine improvement. The process of rewarding and recognising individual teachers' performance should be kept distinct, as far as practicable, from the process of reviewing courses.

For each of the three columns: Publicise definitions of effective teaching and learning; agree criteria; list appropriate sources of evidence; undertake development exercises (eg workshops on how to evaluate a course); set up trustworthy reporting processes.

\begin{tabular}{|lll|}
\hline $\begin{array}{l}\text { Audit and } \\
\text { improvement of the } \\
\text { teaching and learning } \\
\text { environment } \\
\text { (University/Faculty } \\
\text { level) }\end{array}$ & $\begin{array}{l}\text { Audit and } \\
\text { improvement of } \\
\text { courses } \\
\text { (Faculty/School level) }\end{array}$ & $\begin{array}{l}\text { Recognising and } \\
\text { rewarding teaching } \\
\text { (Individual level) }\end{array}$ \\
\hline $\begin{array}{l}\text { Academic staff profile } \\
\text { analysis (eg } \\
\text { qualifications) }\end{array}$ & $\begin{array}{l}\text { Quality of learning } \\
\text { and teaching (eg } \\
\text { quality of teaching } \\
\text { process; staff-student } \\
\text { relationships and } \\
\text { course ethos) }\end{array}$ & $\begin{array}{l}\text { Planning and } \\
\text { preparation for } \\
\text { teaching (eg teaching } \\
\text { sessions have clear } \\
\text { goals for learning) }\end{array}$ \\
\hline
\end{tabular}




\begin{tabular}{|c|c|c|}
\hline $\begin{array}{l}\text { Staff professional } \\
\text { activities (eg teaching } \\
\text { grants secured) }\end{array}$ & $\begin{array}{l}\text { Quality and relevance } \\
\text { of subjects and } \\
\text { courses (eg expert } \\
\text { review, including } \\
\text { external stakeholders; } \\
\text { links between } \\
\text { subjects) }\end{array}$ & $\begin{array}{l}\text { Processes of teaching } \\
\text { (e.g explanations, and } \\
\text { questions are clear and } \\
\text { at appropriate level) }\end{array}$ \\
\hline $\begin{array}{l}\text { Staff development (eg } \\
\text { participation in } \\
\text { seminars and courses) }\end{array}$ & $\begin{array}{l}\text { Student progress and } \\
\text { achievement (eg } \\
\text { quality of learning } \\
\text { outcomes; } \\
\text { responsiveness to } \\
\text { particular needs) }\end{array}$ & $\begin{array}{l}\text { Assessment of } \\
\text { students and their } \\
\text { learning outcomes (eg } \\
\text { students obtain high } \\
\text { quality }\end{array}$ \\
\hline $\begin{array}{l}\text { Faculty management: } \\
\text { leadership and } \\
\text { planning (eg } \\
\text { effectiveness of } \\
\text { Dean's leadership in } \\
\text { shaping the learning } \\
\text { and teaching } \\
\text { environment) }\end{array}$ & $\begin{array}{l}\text { Management for } \\
\text { excellence in teaching } \\
\text { and learning: } \\
\text { leadership and } \\
\text { planning (eg } \\
\text { effectiveness of } \\
\text { Head's leadership in } \\
\text { promoting successful } \\
\text { learning and teaching) }\end{array}$ & $\begin{array}{l}\text { Evaluating and } \\
\text { improving teaching } \\
\text { (eg information from } \\
\text { assessment used to } \\
\text { modify teaching) }\end{array}$ \\
\hline $\begin{array}{l}\text { Evaluation processes } \\
\text { (eg surveys of student } \\
\text { experiences and their } \\
\text { effects) }\end{array}$ & $\begin{array}{l}\text { Evaluation processes } \\
\text { (eg existence of } \\
\text { effective methods for } \\
\text { monitoring student } \\
\text { progress) }\end{array}$ & $\begin{array}{l}\text { Subject/course } \\
\text { coordination and } \\
\text { leadership in teaching } \\
\text { (eg models good } \\
\text { practice and } \\
\text { innovation in } \\
\text { teaching) Scholarship } \\
\text { in teaching (eg } \\
\text { publications on } \\
\text { teaching) }\end{array}$ \\
\hline
\end{tabular}

\section{FIGURE 3}

A Qualitative Performance Indicator for an Undergraduate Course

\section{Indicator TL3: Assessment as part of teaching and learning}

Varied methods, well-matched to aims and objectives, are used

Assessment accurately tests and encourages understanding, application, concepts, skills — not memory alone

An appropriate range of assessment methods, both formal and informal, is used

Teachers are knowledgeable about students' levels of performance

Teachers use assessment to seek out students' difficulties

Information about progress is regularly and freely given; assessment helps students to find out where they have gone wrong

Students are involved in dialogue about their achievements

Assessment is designed to help students develop self-evaluation skills and responsibility for their own learning

Good use is made of assessment information to evaluate the effectiveness of teaching, and to change teaching strategies in order to improve student learning 
FIGURE 4

Griffith Institute for Higher Education: Principles of Quality Management for Teaching and

Learning

- Quality improvement is a primary purpose

- Evaluation should seek to empower staff

- Focus on the quality of learning rather than the teaching process

- Quality outcomes matter more than the existence of quality procedures

- The distinctive mission of the University is vital

- Self-evaluation with stakeholder input should precede external audit

- International referencing is expected

- Excessive use of student questionnaires must be avoided

- Course evaluation is separate from subject and teaching evaluation

- Good teaching should be recognised and rewarded by appropriate behaviours rather than symbolic gestures

- Leadership in teaching and learning is crucial

Out of the process of self-evaluation, which will have identified strengths to build upon and weaknesses that need to be addressed, groups of teachers devise development plans to improve the quality of their courses and their students' learning. These plans then become performance objectives against which they and external auditors can evaluate progress made. This evaluation process is facilitated by the use of quantitative indicators of effectiveness such as the results of the Course Experience Questionnaire, ${ }^{22}$ results from employer surveys, and data about student completion and progression. These quantitative indicators are useful for confirming strengths and weaknesses, assessing improvement, and assisting inter-university cooperation and sharing of good practice. The scheme at the Royal Melbourne Institute of Technology (RMIT) makes similar use of descriptions of criteria and examples of different levels of performance, and again emphasises the importance of developing ownership of the evaluation process through dialogue. An example of the results of this work - showing the development of self-assessment criteria — appears in Figure 5. The RMIT procedures involve individual lecturers' reports to course coordinators and course coordinators' reports to “Directors of Teaching”.

\section{FIGURE 5}

Levels of performance for "Quality of the Teaching Process" (sub theme "Clarity of questions/explanations

and linking topics”)

(Two levels of performance written by a group of social science lecturers to evaluate their own teaching)

\section{Excellent performance:}

"Teachers clearly introduce concepts, stress key ones, and make links between them. They use language that most students find comprehensible. Concepts and explanations are demonstrated in examples that are relevant to the experience of most students. Learning is centred around the application of ideas, not the repetition of words. Concepts are introduced in steps, moving from simple to complicated; teachers check at each stage that students understand. Topics are introduced in logical sequence. Classes are well presented and handled. As a result, most students can recognise and use explanations and theories in new cases.”

\section{Performance showing more weaknesses than strengths:}

"Teachers present concepts and explanations unsystematically. There is little attempt to link them to the experiences and understandings that students already possess. Concepts, explanations and topics are not connected logically, and teachers do not always ensure that students understand at each stage. Expositions are not satisfactory; there is evidence that materials such as visuals and handouts are not well prepared and not closely linked to presentations. As a result, many students can echo the teachers' words but not use the concepts 
Both these schemes imply the need for leadership development programmes, since so much of the effectiveness of a rigorous self-evaluation process depends on strong support from senior staff. Both also involve the support of designated leadership positions which the respective academic development units have worked to establish in cooperation with senior management. RMIT has its "Directors of Teaching" and Griffith has its Deputy Deans (Teaching and Learning). The importance attached to these posts is reflected in the emoluments they attract and the heavy responsibilities they demand. The function of their incumbents is to educate, enable, introduce new ideas, model best practice, and remove impediments to excellent teaching and learning. They signify a conception that the quality of learning and teaching is an issue that should be tackled by the smallest academic units that can deliver it, a view entirely compatible with the quality movement beyond higher education.

\section{CONTRASTING MODELS OF LEARNING AND TEACHING}

The main ideas about improving teaching, educational leadership in universities, and evaluation I have been trying to express may be placed in their wider context by reference to the two different models shown in Figure 6. ${ }^{23}$

\section{FIGURE 6}

Contrasting Models of Teaching, Educational Leadership, and Evaluation in Higher Education

\begin{tabular}{|c|c|c|}
\hline & $\begin{array}{c}\text { Model I: } \\
\text { "Disseminating } \\
\text { knowledge” }\end{array}$ & $\begin{array}{l}\text { Model II: } \\
\text { "Making } \\
\text { learning } \\
\text { possible" }\end{array}$ \\
\hline $\begin{array}{l}\text { Epistemological } \\
\text { assumptions }\end{array}$ & $\begin{array}{l}\text { Knowledge exists } \\
\text { separately from the } \\
\text { people who possess it. } \\
\text { Knowledge can be } \\
\text { conveyed. Concepts and } \\
\text { facts are prerequisites } \\
\text { for problem-solving in a } \\
\text { field of study. Theory } \\
\text { and practice are separate } \\
\text { domains. }\end{array}$ & $\begin{array}{l}\text { Knowledge doesn't } \\
\text { exist apart from } \\
\text { people. Knowledge } \\
\text { must be reconstructed } \\
\text { by learners. Facts and } \\
\text { concepts are learned } \\
\text { as they are used. } \\
\text { Problem-solving, } \\
\text { concepts and facts are } \\
\text { mutually dependent, } \\
\text { in learning as well as } \\
\text { in expert practice. }\end{array}$ \\
\hline Evaluation and audit & $\begin{array}{l}\text { Measurement focused, } \\
\text { externally directed and } \\
\text { value-free. Preferred } \\
\text { indicators are } \\
\text { quantitative, such as } \\
\text { pass rates and student } \\
\text { ratings. }\end{array}$ & $\begin{array}{l}\text { Process focused, user } \\
\text { directed and } \\
\text { permeated by values. } \\
\text { Preferred indicators } \\
\text { are qualitative, such as } \\
\text { student comments and } \\
\text { evidence of changes in } \\
\text { conceptions. }\end{array}$ \\
\hline $\begin{array}{l}\text { Educational } \\
\text { effectiveness }\end{array}$ & $\begin{array}{l}\text { Essentially technical: a } \\
\text { problem to be solved. }\end{array}$ & $\begin{array}{l}\text { Essentially } \\
\text { problematic: an } \\
\text { enduring human } \\
\text { dilemma. }\end{array}$ \\
\hline
\end{tabular}

We are seeing a shift from the first model to the second, as undergraduate education becomes more like a mass system and focuses more in developing lifelong learning competence, including generic 
employment-related skills, rather than on preparing a research elite. This changing social context of university education is presumably the reason why research on student learning now seems to be so relevant. The transit to a more student-centred view of undergraduate education has been foreshadowed before, of course, notably at the time of the Hale Report and the founding of the "new" universities in the 1960s; but the momentum was never as great as it is today. It is now, surely, an unstoppable phenomenon.

Model I is essentially a lecturer- and discipline-dominated view of undergraduate teaching and learning. Lecturers teach (or more likely lecture); students do the learning. Its conception of learning is foundationalist: first learn the basics before you go and use your knowledge. It emphasises the idea that learning is a profoundly individual phenomenon. Assessment is largely about marking and classifying and competition. Teaching is improved through practice alone, Evaluation is about "objective" numbers.

The second model is focused on learning and students rather than on teaching. The problem is how to engage people with the things they learn. Its implications are consonant with the findings from student learning research; but more significantly, it reflects the changed environment in which universities in the UK and Australia now find themselves. Model II recognises the importance of the social context of learning and the need in undergraduate education to integrate knowledge with its practical use. It focuses on assessment as part of learning. It stresses the similarities between how experts work and how students should learn to be experts. It embraces views of academic leadership and evaluation such as those I have tried to describe above.

Of course we must not interpret Figure 6 in trivial dualist terms. Knowledge is often cumulative. Good teaching generally does involve good presentation. Effective leadership almost invariably requires transactional strategies as well as transformational insights. Quantitative indicators of performance can marry happily with qualitative ones. Grading students is not a bar to giving good feedback and focusing on formative processes. Producing publicly-verifiable data on educational performance should go hand in hand with self-evaluation. It is a matter of emphasis and not of simple dualities; it is a matter of balancing and integrating apparent opposites in an educationally valid way. Remembering Minton's conclusions about the right questions and what makes the difference between quality and mediocrity, an understanding of the last row of Figure 6 is the one that matters most. We will continue to return to the same issues as we try to improve our students' learning, our management of university teaching, and our evaluation of the effectiveness of higher education. In approaching these issues the search for right answers is a snare and a delusion. "Many of the issues facing teachers are not problems to be solved" says Welker. "They are dilemmas to be repeatedly encountered. Dilemmas don't require answers; they require enduring human responsibility". ${ }^{24}$

1 This article is based on a keynote paper presented at the First International Improving Learning Symposium held at Warwick University in September 1993. An earlier version appears in G Gibbs ed Improving Student Learning: Theory and Practice. Oxford: Oxford Centre for Staff Development.

2 D. Minton, Teaching Skills in Further and Adult Education (Basingstoke: Macmillan 1991).

3 TJ Shuell, Cognitive Conceptions of Learning (1986) 56 Rev of Ed Research 411; JB Biggs, Teaching: Design for Learning in B Ross (ed) Teaching for Effective Learning (Sydney: HERDSA 1990); JB Biggs, From Theory to Practice: a Cognitive Systems Approach (1993) 12 Higher Ed Research and Dev 73.

4 K Trigwell \& M Prosser, Approaches Adopted by Teachers of First Year. University Science Courses, in A Viskovic ed Towards 2000: Trends in Tertiary Teaching (1993) 14 Research and Development in Higher Education 223; KS Cushing, DS Sabers \& DC Berliner, Olympic Gold: Investigations of Expertise in Teaching (1992) Educ Horizons 108.

5 D Bligh, Review of Learning to Teach in Higher Education (1993) 18 Studies in Higher Educ 105.

6 It also makes the nature of the error invisible to those who have the conception, an effect that has been noted in phenomenographic studies of learning.

7 K Trigwell M Prosser \& P Taylor, Qualitative Differences in Approaches to Teaching First Year Science Courses (1994) 27 Higher Educ 75.

8 Bligh supra note 5; L Andreson, Many Roads to One Place: Which Place? Which Roads? Paper presented to the Invitational Symposium on the Experience of Quality in Higher Education, Griffith Institute for Higher Education, Griffith University, 3-5 July 1994; Staff and Educational Development Association (SEDA) The Accreditation of Teachers in Higher Education (Birmingham: SEDA, 1994)

9 DA Schön, Educating the Reflective Practitioner (San Francisco: Jossey-Bass, 1987).

10 E Martin \& P Ramsden, Evaluation of the Performance of Courses in Teaching Methods for Recently Appointed Staff (Canberra: AGPS, 1994). 
11 R Boice The New Faculty Member: Supporting and Fostering Professional Development (San Francisco: Jossey Bass, 1992).

12 KS Louis, Beyond Bureaucracy: Rethinking How Schools Change, invited address, International Congress for School Effectiveness and Improvement, Norrkoping, January 1993.

13 GA Donaldson Learning to Lead: The Dynamics of High School Principalship (New York: Greenwood Press, 1991).

14 Louis supra note 12; P Ramsden Learning to Teach in Higher Education (London: Routledge, 1992) ch. 6.

15 CJ Bland \& MT Ruffin, Characteristics of a Productive Research Environment: Literature Review (1992) 67 Academic Medicine 385.

16 See for example K Samuelowicz \& JD Bain, Conceptions of Teaching Held by Academic Teachers (1992) 24 Higher Educ 93.

17 K Trigwell, P Ramsden, P Martin \& M Prosser, Teaching Approaches and leadership Environment, paper presented at the Annual Conference of HERDSA, Rockhampton, July 1995.

18 I am indebted to Lee Harvey for this way of expressing the association.

19 Scottish Office Education Department (SOED) Using Performance Indicators in Secondary School Self-Evaluation (Edinburgh: SOED, 1992)

20 I am not able to go into the evaluation of individual teaching performance in this article, but the development of criteria and the use of individual portfolios in order to help recognise and reward good teaching is part of the wider scheme.

21 Based on material on SOED, supra note 19.

22 J Ainley \& M Long The Course Experience Survey: 1992 Graduates (Canberra: AGPS, 1994).

23 I am most grateful to John Bain for allowing me to adapt his original ideas and table into the present form.

24 R Welker, Reversing the Claim on Professional Status: What Educators can Teach Experts (1992) Educational Horizons 115. 